Final draft version (do not cite). Final version published in International Criminal Law

Review 17(6):1049-1069 05 Dec 2017

\title{
The Nuremberg Doctors' Trial: Looking Back 70 Years Later
}

\author{
Xavier Aurey
}

Lecturer, University of Essex, U.K. PhD, University Panthéon-Assas Paris 2, France.

\begin{abstract}
On 20 August 1947, the United States Military Tribunal condemned sixteen persons in Nuremberg for crimes committed in the name of science in several concentration camps. Moving away from a dichotomous stance delineating true science/false science, the judges were able to outline ten ethical and legal principles to regulate all clinical experiments, which were subsequently known as the "Nuremberg Code". Where most of legal commentaries focus on the mere reading of these ten principles, this paper will highlight some of the steps in the legal journey of the American judges. We will see that, unfortunately, they have failed to address one of the most difficult issues in clinical trials and human experimentation: the almost unavoidable context of exploitation of any situation where a person is used as an object for the good of others.
\end{abstract}

\section{Keywords}

Nuremberg, Doctors' trial, concentration camps, bioethics, crimes against humanity, human experimentation, medical crimes, Martens Clause

It has now been seventy years since a United States military tribunal tried twenty-three people in Nuremberg, including twenty doctors and medical researchers, ${ }^{1}$ for war crimes and crimes against humanity. They were accused of having constituted a collection of skeletons, implementing the T4 euthanasia program and having carried out medical experiments ${ }^{2}$ on prisoners in the concentration camps at Auschwitz, Buchenwald, Dachau, Natzweiler, Ravensbrück and Sachsenhausen between September 1939 and April 1945 - the period over which the tribunal had jurisdiction. Of the twenty-three defendants, seven were acquitted, seven sentenced to death ${ }^{3}$ and the others given prison sentences of at least ten years. ${ }^{4}$

This trial (Karl Brandt and others) ${ }^{5}$ was set up by the authority responsible for the American Zone of Occupation, the Office of Military Government, United States (OMGUS), which in

\footnotetext{
${ }^{1}$ Among the doctors and medical researchers were Karl Brandt (Hitler's personal doctor), Siegfried Handloser (Chief of German Armed Forces Medical Service), Paul Rostock (Chief of the Office for Medical Science and Research), Oskar Schroeder (Chief of German Air Force Medical Service), Karl Genzken (Chief of Waffen SS Medical Service) and Karl Gebhardt (Heinrich Himmler's personal doctor and President of the German Red Cross).

${ }^{2}$ High altitude experiments, freezing experiments, malaria experiments, mustard gas experiments, sulfonamide experiments, bone transplantation and bone muscle and nerve regeneration experiments, sea water experiments, jaundice experiments, sterilization experiments, typhus experiments, poison experiments, phosphorus burns experiments.

${ }^{3}$ Namely Viktor Brack, Karl Brandt, Rudolf Brandt, Karl Gebhardt, Waldemar Hoven, Joachim Mrugowsky, and Wolfram Sievers.

${ }^{4}$ For an accurate analysis of this trial, $c f$. Yves Ternon, 'Le procès des médecins. Actualisation', 160 Revue d'histoire de la Shoah (1997) pp. 10-30.

${ }^{5}$ United States of America vs. Karl Brandt and al. (case n ${ }^{\circ}$ ), 20 August 1947, United States Military Tribunal.
} 
October 1946 created the United States Military Tribunal. ${ }^{6}$ It was the first of the trials carried out under article 6 of the London Agreement of 8 August $1945^{7}$ and Law no. 10 issued by the Allied Control Council on 20 December $1945 .^{8}$ The trial began on 9 December 1946, coming to an end less than a year later, with pronouncement of the verdicts and sentences respectively on 19 and 20 August 1947.

Two years after the end of this trial, twelve former members of the Japanese armed forces, including six members of Unit $731^{9}$ and two members of Unit $100,{ }^{10}$ were tried in the USSR. This one is far less well-known than its American counterpart, ${ }^{11}$ taking place from 25-30 December 1949 in the city of Khabarovsk. ${ }^{12}$ According to the indictment of 16 December 1949 drawn up by Prosecutor Berezovsky, ${ }^{13}$ the defendants were accused of having tested biological weapons on Russian and Chinese prisoners. The indictment thus mentions biological weapons tests which aimed at spreading different diseases and bacteriological agents such as typhoid fever, the plague, cholera or tuberculosis. ${ }^{14}$ It also mentions experiments conducted on women to test ways of treating syphilis as well as experimental treatment for limbs, which incurred their previous freezing. One defendant, Kawashima Kiyochi, stated during the trial that at least 600 people died every year due to the experiments carried out within Unit 731. ${ }^{15}$ According to Matsumura Tomokatsu's testimony, these experiments on humans were given the green light by the Commander-in-Chief Kenkichi Ueda, and by his successor Yoshijirō Umezu. ${ }^{16}$ All the defendants pleaded guilty and were given sentences ranging from 3 to 25 years in a labour camp.

Conversely, the Nuremberg defendants did not plead guilty, and this is in large part due to the defense's argument, which sought to draw a parallel between the experiments carried out in Nazi Germany, and those which were being performed everywhere else in the world,

\footnotetext{
${ }^{6}$ USA, OMGUS, Ordinance $n^{\circ} 7$. Organization and powers of certain military tribunals, 18 October 1946.

${ }^{7}$ London Agreement, 8 August 1945, reproduced in Trial of the Major War Criminals before the International Military Tribunal, Volume I: Official Documents (International Military Tribunal Secretariat, 1947), pp. 8-19.

${ }^{8}$ Allied Control Council, Control Council Law No. 10, Punishment of Persons Guilty of War Crimes, Crimes Against Peace and Against Humanity, 20 December 1945, especially Article 3 recognizing the right of each occupying authority to undertake proceedings against people accused of the crimes in question.

${ }^{9}$ Unit 731, otherwise known as the Epidemic Prevention and Water Purification Department of the Kwantung Army (a group of the Japanese Imperial Army established in Kwantung) was founded in 1936 by a secret decree issued by Emperor Hirohito, according to Kawashima Kiyoshi's testimony. It was directed by Ishii Shiro and stationed in Pingfang, one of the districts of Harbin, in the puppet state of Manchukuo. Many prisoners of war were used there as guinea pigs for experiments, particularly on the plague and cholera. $C f$. Daniel Barenblatt, $A$ Plague Upon Humanity: The Secret Genocide of Axis Japan's Germ Warfare Operation (HarperCollins, New York, 2004).

${ }^{10}$ Unit 100, otherwise known as the Kwantung Army Warhorse Disease Prevention Shop was stationed in Mokotan, a village close to the city of Changchun in the state of Manchukuo. It was directed by Yujiro Wakamatsu. It was supposed to work on animal diseases, but experiments on humans were also carried out there. ${ }^{11}$ Jing-Bao Nie, 'The West's Dismissal of the Khabarovsk Trial as "Communist Propaganda”. Ideology, evidence and international bioethics', 1(1) Journal of Bioethical Inquiry (2004) 32-42.

${ }^{12}$ This trial took place on the basis of the decree issued by the Presidium of the Supreme Soviet on 19 April 1943, relating to war crimes committed during the Second World War and defining manufacture and use of biological weapons as a war crime. Cf. Materials on the Trial of Former Servicemen of the Japanese Army Charged with Manufacturing and Employing Bacteriological Weapons (Foreign Languages Publishing House, Moscow, 1950). For further elements on medical crimes committed by Japanese doctors and on the Khabarovsk trial, $c f$. Jing-Bao Nie, Nanyan Guo, Mark Selden, Arthur Kleinman (eds.), Japan's Wartime Medical Atrocities. Comparative inquiries in science, history and ethics (Routledge, New York, 2010), particularly the article by Boris G. Yudin, 'Research on humans at the Khabarovsk War Crimes Trial: a historical and ethical examination', pp. 59-78.

${ }^{13}$ Materials on the Trial, supra note 12, p. 15 ss.

${ }^{14}$ Ibid.

${ }^{15}$ Ibid., p. 20.

${ }^{16}$ Ibid., p. 138.
} 
particularly in the United States. ${ }^{17}$ It should not be forgotten that even as the Nuremberg trial was going on, American researchers continued infecting African-Americans in Tuskegee with syphilis, ${ }^{18}$ and more than 1300 Guatemalan prisoners - without their consent - with the same disease in addition to gonorrhoea and chancroid to subsequently study how they progressed, with or without treatment. ${ }^{19}$

The Nuremberg Doctors' Trial is thus located at a crossroads where three types of issues intersect: military ones, scientific ones and ideological ones. Military ones because this trial was related to all of the other trials aimed at prosecuting war crimes and crimes against humanity committed by the Nazi state during the Second World War. Scientific ones because the trial was specifically aimed at acts carried out during this period by German researchers and doctors on people who were treated as mere guinea pigs. And lastly ideological ones because the courtroom was the theatre of a confrontation between two conflicting visions: on the one hand, a relativistic and totalitarian vision which asserted the supremacy of the social body over the individual ${ }^{20}$ and on the other a universalist and liberal vision which contended that it was the individual who had precedence over society. ${ }^{21}$

In his opening statement, Prosecutor Telford Taylor appeared to mainly focus on the latter issues to pinpoint the reasons and the motives which led to the dehumanization of the victims. ${ }^{22} \mathrm{He}$ thus pointed to the "prostitution" 23 of doctors and medical science to Nazi ideology. However, whereas for him the crime was almost biomedical, "committed in the

\footnotetext{
${ }^{17} C f$. notably Jon M. Harkness, 'Nuremberg and the issue of wartime experiments on US prisoners. The Green Committee', 276(20) JAMA (1996) p. 1674.

${ }^{18}$ Since 1932, the United States Public Health Service had been carrying out a study on syphilis using AfricanAmerican individuals, who were suffering from the disease and not receiving treatment, in order to determine the natural progression of the disease without any medication acting upon it. This study only came to an end in 1972 when it was uncovered to the public by Jean Heller, 'Syphilis Victims in U.S. Study Went Untreated for 40 Years', New York Times, 26 July 1972. Concerning this affair, cf. among others James H. Jones, Bad Blood: The Tuskegee Syphilis Experiment (The Free Press, New York, 1981); Susan M. Reverby, Examining Tuskegee: The Infamous Syphilis Study and its Legacy (University of North Carolina Press, Chapel Hill, 2009). Other similar studies were carried out in Sweden between 1891 and 1955, cf. L. W. Harrison, 'The Oslo study of untreated syphilis', 32 British Journal of Venereal Diseases (1956) 70-78 (the author cites the 'Alabama group').

${ }^{19}$ This last test was carried out between 1946 and 1948 and was only revealed to the public in 2010. Cf. U.S. Presidential Commission for the Study of Bioethical Issues, Ethically impossible: STD research in Guatemala from 1946 to 1948, 2011; Susan M. Reverby, 'Ethical Failures and History Lessons: The U.S. Public Health Service Research Studies in Tuskegee and Guatemala', 34(1) Public Health Reviews (2012) 1-18.

${ }^{20} \mathrm{Cf}$. notably Robert N. Proctor, 'Nazi Doctors, Racial Medicine, and Human Experimentation', in George J. Annas, Michael A. Grodin (eds.), The Nazi Doctors and the Nuremberg Code. Human Rights in Human Experimentation (Oxford University Press, Oxford, 1992), pp. 17-31; Jean-Pierre Baud, 'Genèse institutionnelle du génocide', in Josiane Olff-Nathan (ed.), La science sous le Troisième Reich (Editions du Seuil, Paris, 1993), pp. 177-195; Robert N. Proctor, 'Nazi medical ethics: ordinary Doctors?', Military Medical Ethics, vol. 2 (Office of The Surgeon General, Department of the Army, United States of America, 2003), pp. 403-436

${ }^{21}$ Cf. notably François De Smet, Les Droits de l'homme. Origines et aléas d'une idéologie moderne (Cerf, Paris, 2001); Samuel Moyn, The Last Utopia. Human Rights in History (Harvard University Press, Cambridge, 2010); Olivier Barsalou, La diplomatie de l'universel: la guerre froide, les Etats-Unis et la genèse de la Déclaration universelle des droits de l'Homme, 1945-1948 (Bruylant, Brussels, 2012); Michael Robert Marrus, 'The Nuremberg Doctors' Trial in Historical Context', 73(1) Bulletin of the History of Medicine (1999) 106-123; Ruth Macklin, 'Universality of the Nuremberg Code', in George J. Annas, Michael A. Grodin (eds.), The Nazi Doctors and the Nuremberg Code. Human Rights in Human Experimentation (Oxford University Press, Oxford, 1992), pp. 240-257.

${ }^{22}$ Telford Taylor, 'Opening statement of the prosecution, December 9, 1946', Trials of War Criminals before the Nuernberg Military Tribunals Under Control Council Law $n^{\circ} 10$, vol. I: 'The Medical Case', Nuernberg, October 1946 - April 1949 (U.S. Government Printing Office, Washington, 1950), pp. 27-28.

${ }^{23}$ Ibid., pp. 56 and 58.

${ }^{24}$ With reference to the work by Marcela Iacub, Le crime était presque sexuel et autres essais de casuistique juridique (Epel, Paris, 2002).
} 
Final draft version (do not cite). Final version published in International Criminal Law

Review 17(6):1049-1069 05 Dec 2017

name of medical science ${ }^{, 25}$ yet without being scientific, ${ }^{26}$ the developments of the trial would lead the court to take a different stance. Thinking in terms of the three types of issues listed above - military, scientific and ideological - the judges would define rules for a system of protection of bodily integrity for people regarding experiments on human beings. Moving away from a dichotomous stance delineating true science/false science, they were able to outline ten ethical and legal principles to regulate all clinical experiments, ${ }^{27}$ which were subsequently known as the "Nuremberg Code".

Where most legal commentaries thus focus on the mere reading of these ten principles, some authors even writing on the "lost truth of the Nuremberg Code", ${ }^{28}$ I would like to highlight some of the steps in the legal journey of the American judges. Starting from the Martens Clause, they tried to find their path through international medical ethics. Unfortunately, they failed to address one of the most difficult issues in clinical trials and human experimentation: the almost unavoidable context of exploitation of any situation where a person is used as an object for the good of others.

\section{Nuremberg and a Minimum Level of Humanity}

For the judges at the Doctors' Trial, the medical and scientific experiments carried out by the Nazi doctors,

involving brutalities, tortures, disabling injury, and death were performed in complete disregard of international conventions, the laws and customs of war, the general principles of criminal law as derived from the criminal laws of all civilized nations, and Control Council Law No. 10. Manifestly human experiments under such conditions are contrary to "the principles of the law of nations as they result from the usages established among civilized peoples, from the laws of humanity, and from the dictates of public conscience". ${ }^{29}$

Although they did not directly quote it, the formulation placed into quotation marks by the judges is a restatement of the final words of the Martens Clause. Also quoted, but this time explicitly, in the Krupp judgment ${ }^{30}$, this clause would - according to Theodor Meron -

\footnotetext{
${ }^{25}$ Taylor, supra note 22, p. 27.

${ }^{26}$ Ibid., p. 61: 'Many of these were experiments in name only; we will show them to have been senseless and clumsy and of no real value to medicine as a healing art'. The question of scientific quality as an ethical and/or legal criterion will be explored in the second part of the article.

${ }^{27}$ Cf. notably: Philippe Amiel, François Vialla, 'La vérité perdue du "code de Nuremberg": réception et déformations du "code de Nuremberg" en France', 2009(4) Revue de droit sanitaire et social (2009) 673-687 ; George J. Annas, Michael A. Grodin (eds.), The Nazi Doctors and the Nuremberg Code, Oxford University Press, 1992; Paul Weindling, 'Le Code de Nuremberg, Andrew Conway Ivy et les crimes de guerre médicaux nazis', in Christian Bonah, Etienne Lepicard, Volker Roelcke (eds.), La médecine expérimentale au tribunal. Implications éthiques de quelques procès médicaux au XXe siècle europée (Edition des archives contemporaines, Paris, 2003), pp. 185-213.

${ }_{28}^{28}$ Amiel and Vialla, ibid., pp. 673-687.

29 'Judgment', Trials of War Criminals before the Nuernberg Military Tribunals Under Control Council Law $n^{\circ} 10$, vol. II: 'The Medical Case' - continued, Nuernberg, October 1946 - April 1949 (U.S. Government Printing Office, Washington, 1950), p. 183 [emphasis added].

${ }^{30}$ US Military Tribunal at Nuremberg, US v. Alfried Krupp et al., 'Judgement', vol. IX, 'Krupp Case', p. 1341. The American judges were able to assert in this affair that the Martens Clause as stated in the Preamble to the
} 
provide a response to assertions that the Nuremberg Charter merely constituted retroactive penal legislation. ${ }^{31}$ In 1899 , the contracting Parties to the Hague Convention (II) on the Laws and Customs of Wars on Land agreed that for all cases not specifically covered by the provisions of the Convention, 'populations and belligerents remain under the protection and empire of the principles of international law, as they result from the usages established between civilized nations, from the laws of humanity, and the requirements of the public conscience'. ${ }^{32}$ Repeated in the Preamble to the Hague Convention (IV) on the Laws and Customs of War on Land (1907) $)^{33}$, the Martens Clause ${ }^{34}$ affirms a minimum of humanity, these 'elementary considerations of humanity, even more exacting in peace than in war' according to the formula of the International Court of Justice. ${ }^{35}$ It sets down the minimum requirement level of humanity in situations for which no other rule has been stipulated. It is a normative minimum below which any act against a person is illegal, and below which no necessity can become law.

In foundational and legal terms, the rules of war revolve around the notion of military necessity and the framework for this. ${ }^{36}$ Indeed, the notion and its framework is the raison d'être for the normative base. The preamble to the Saint Petersburg Declaration of 11 December 1868 provides an interesting example in that it affirms 'the necessities of war ought to yield to the requirements of humanity'. ${ }^{37}$ In order to be justified, an act committed in the context of an armed conflict must reconcile military necessity with obligations in terms of

1907 Convention, 'is much more than a pious declaration. It is a general clause, making the usages established among civilized nations, the laws of humanity, and the dictates of public conscience into the legal yardstick to be applied if and when the specific provisions of the Convention and the Regulations annexed to it do not cover specific cases occurring in warfare, or concomitant to warfare'. A citation notably underlined by Judge Shahabuddeen in his dissenting opinion at the Legality of the Threat or Use of Nuclear Weapons, 8 July 1996 , International Court of Justice, Advisory opinion, p. 407.

31 'In Nuremberg, the Martens clause was invoked mainly in response to assertions that the Nuremberg Charter, as applied by the tribunals, constituted retroactive penal legislation'. It was necessary to show that the incriminations as laid out by the statutes of the Nuremberg IMT Nuremberg, or in the shape of Law No. 10 of the Allied Control Council, were, in reality, simply the formalization of earlier laws and customs and which were not actually new penal provisions applied retroactively. See Theodor Meron, 'The Martens Clause, Principles of Humanity, and Dictates of Public Conscience', 94(1) The American Journal of International Law (2000), p. 80.

${ }^{32}$ Convention (II) on the Laws and Customs of War on Land, The Hague, 29 July 1899, Preamble, al. 8.

${ }^{33}$ Convention (IV) on the Laws and Customs of War on Land, The Hague, 18 October 1907, Preamble, al. 8.

${ }^{34}$ The clause derived from a statement by Professor Frédéric de Martens, made in reaction to the inability of the delegates at the 1899 Conference to come to an agreement on the status of civilians who take up arms against an occupying power. For the developments surrounding this clause, its history and its impact, cf. notably Antonio Cassese, 'The Martens Clause: Half a Loaf or Simply Pie in the Sky ?', 11(1) European Journal of International Law (2000) 187-216; Meron, supra note 31, pp. 78-89; Rupert Ticehurst, 'The Martens Clause and the Laws of Armed Conflict', 317 International Review of the Red Cross (1997), p. 824. Mika Nishimura Hayashi, 'The Martens Clause and Military Necessity', in Howard M. Hensel (ed.), The legitimate Use of Military Force (Routledge, New York, 2013), pp. 135-160.

${ }^{35}$ Corfu Channel Case (United Kingdom v. Albania), 9 April 1949, International Court of Justice, ICJ Reports 1949, p. 22.

${ }^{36}$ On the notion of military necessity, $c f$. notably Nobuo Hayashi, 'Requirements of Military Necessity in International Humanitarian Law and International Criminal Law', 28 Boston University International Law Journal (2010) 39-140; Nils Melzer, 'Keeping the balance between military necessity and humanity: a response to four critiques of the ICRC's interpretive guidance on the notion of direct participation in hostilities', 42 International Law and Politics (2010) 831-916.

${ }^{37}$ Declaration Renouncing the Use, in Time of War, of Explosive Projectiles Under 400 Grammes Weight, 11 December 1868, in International Law Institute Yearbook, 1877, vol. I, pp. 306-307. The signatories of this Declaration thus proposed to ban use of 'any projectile of a weight below 400 grammes, which is either explosive or charged with fulminating or inflammable substances'. 
humanity. ${ }^{38}$ The first problem which was raised at Nuremberg was not so much knowing whether military necessity could be used as an excuse for any experiments on human subjects but defining to what extent, in an armed conflict, the notions of military necessity - both in terms of what it allowed as well as what it restricted - and the requirements of humanity could be used to regulate conducting tests on human beings in the absence of a specific applicable rule.

Under questioning, Karl Brandt ${ }^{39}$ thus underlined that experiments with mustard gas had been carried out by all supposedly civilized nations since the First World War. ${ }^{40}$ The United Kingdom was, it seems, at the forefront in terms of experiments on humans. ${ }^{41}$ According to Brandt, the need for scientific research was then recognized by all nations as a military necessity, ${ }^{42}$ and such research was carried out under the auspices and the control of the state. ${ }^{43}$ It was with this in mind that the defendants and their lawyers would seek to justify the experiments carried out as being for reasons of military necessity, namely, everything 'essential to the fatherland's war effort'. ${ }^{44}$ They also underlined that this necessity is one of the conditions for the legality of experiments on humans, ${ }^{45}$ and that these experiments should not be conducted beyond what was necessary to ensure the resolution of the problem at hand. ${ }^{46}$ By employing these arguments, they made use of the two facets of necessity: permissive - doing what is necessary - and restrictive - only doing what is necessary. ${ }^{47}$

\footnotetext{
${ }^{38}$ Initially, the now somewhat antiquated idea of chivalry was coupled to these two founding principles of the laws on armed conflict. Cf. notably Lassa F. L. Oppenheim, International Law, Volume II, Disputes, War and Neutrality, $7^{\text {th }}$ edition (Longmans and Green, London, 1952), pp. 226-227.

${ }^{39}$ Hitler's personal doctor since 1934, Karl Brandt was lieutenant general of the Waffen-SS and Reich Commissioner for Health and Public Hygiene. He notably took charge of the program of euthanasia for disabled and mentally ill people, called 'Aktion T4'. For a critical biography of this Nazi doctor, reference can be made to Ulf Schmidt, Karl Brandt: the Nazi Doctor. Medicine and Power in the Third Reich (Hambledon continuum, London, 2007).

${ }^{40} C f$. notably Susan L. Smith, 'Mustard Gas and American Race- Based Human Experimentation in World War II', 36(3) Journal of Law, Medicine \& Ethics (2008) 517-521; Hugh R. Slotten, 'Humane Chemistry or Scientific Barbarism? American Responses to World War I Poison Gas, 1915-1930', 77(2) The Journal of American History (1990) 476-498.

${ }^{41}$ Cf. in this respect Marion Girard, A Strange and Formidable Weapon: British Responses to World War I Poison Gas (University of Nebraska Press, Lincoln, 2008).

42 'Extract from the closing brief for defendant Karl Brandt', Trials of War Criminals before the Nuernberg Military Tribunals Under Control Council Law n 10, vol. I: 'The Medical Case’, Nuernberg, October 1946 April 1949 (U.S. Government Printing Office, Washington, 1950), p. 325.

${ }^{43}$ In terms of the Nazi state, Yves Ternon underlines that 'These experiments had often been planned in Berlin during conferences which brought together dozens of officials responsible for health services and during which the opportunity of carrying out experimental research had been discussed according to the necessities arising from the war', $c f$. Ternon, supra note 4, p. 17. $C f$. also Robert N. Proctor, 'Nazi Doctors, Racial Medecine, and Human Experimentation', in George J. Annas, Michael A. Grodin (ed.), The Nazi Doctors and the Nuremberg Code. Human Rights in Human Experimentation (Oxford University Press, Oxford, 1992), pp. 17-31.

44 'Extracts from the closing brief for defendant Ruff', Trials of War Criminals before the Nuernberg Military Tribunals Under Control Council Law $n^{\circ} 10$, vol. I: 'The Medical Case', Nuernberg, October 1946 - April 1949 , (U.S. Government Printing Office, Washington, 1950), p. 124 ; cf. also ibid., p. 542 (Mrugowsky’s defense); ibid, vol. II: 'The Medical Case' - continued, pp. 5 s. (Gebhardt's defense).

45 'Ruff', Ibid., p. 124.

${ }^{46}$ Ibid., p. 125.

${ }^{47}$ Since the Lieber code, military necessity has been held to be 'the necessity of those measures which are indispensable for securing the ends of the war, and which are lawful according to the modem law and usages of war' (art. 14). Stated thus, this concept has a double purpose, both qualifying acts which are subject to the laws of war (art. 15) and excluding those which cause needles suffering with regard to the aims of the war (art. 16). It thereby has a permissive role - authorizing in time of war acts which are otherwise forbidden - and a restrictive role - forbidding unnecessary and needless harm. Cf. Lieber Code, 24 April 1863 (Instructions for the Government of the Armies of the United States in the Field, written by Francis Lieber during the American Civil War and enacted by President Lincoln under the name of 'General Order No. 100'). On the Lieber code and the
} 
Dr Serviatus, Karl Brandt's lawyer, pushed this line of thought to the furthest limit when he presented the prosecution and the judges with the use of the maxim of 'necessity in war', which, according to him, was accepted when it applied to the Allies but not when it applied to the Nazis. ${ }^{48}$ Deriving from German doctrine, this maxim of 'Kriegsraison geht vor Kriegsmanier ${ }^{49}$ seeks to assert, as Lassa F. L. Oppenheim explains, that 'the laws of war lose their binding force in case of extreme necessity ${ }^{50}$, i.e. in case of extreme danger or when you can defeat the enemy. This means that it would be possible to derogate the already derogating restrictions from ordinary law. ${ }^{51}$ Dr. Serviatus thus put the question of the American use of the atomic bomb on Hiroshima to the court. Why in this case, he asked, could military necessity be used as a reason to violate the 'prohibition of the Hague Convention, under which belligerents have no unlimited right in the choice of methods for inflicting damage on the enemy ${ }^{52}$, and yet not in the case of experiments carried out in the camps? Whether it be necessity in war or military necessity, the aim of this line of argument is to secure that states can always decide to override ordinary law, in a highly Schmittian vision of sovereignty. ${ }^{53}$ And, the supreme imperative that can be derived would apply to the medical field, just as it would to any other.

Faced with this argument, the prosecution countered that no necessity, military or not ${ }^{54}$, could be used to justify the acts carried out by the Nazi doctors. Although it acknowledged that the Nazi state may have viewed these experiments as being necessary and that 'each defendant thought there was some necessity to what he was doing', ${ }^{55}$ the prosecution posited that accepting this necessity of the state ${ }^{56}$ as a means of defending the actions in question would result in the trial losing all sense or meaning. ${ }^{57}$ Yet by doing so, the prosecution aimed at the wrong target and appears to have confused the notions of Kriegsraison and military necessity. The former was only really used by Brandt's lawyer in a provocative way as a means of forcing the American judges to face up to their own contradictions. Correctly rejecting any

principle of military necessity, interesting insight is provided by Burrus M. Carnaha, 'Lincoln, Lieber and the Laws of War: the Origins and Limits of the Principle of Military Necessity', 92 AJIL (1998) 213-231.

48 'Final plea for defendant Karl Brandt by Dr. Servatius', Trials of War Criminals before the Nuernberg Military Tribunals Under Control Council Law $n^{\circ} 10$, vol. II: 'The Medical Case' (U.S. Government Printing Office, Washington, 1950), p. 127.

49 'Necessity in war overrides the way of fighting a war' [personal translation]. For a succinct historical overview of this notion, $c f$. Gary D. Solis, The Law of Armed Conflict: International Humanitarian Law in War (Cambridge University Press, Cambridge, 2010), pp. 265-268.

${ }^{50}$ Lassa F. L. Oppenheim, International Law: a Treatise, vol. II: War and Neutrality, Longmans/Green, 1906, p. 79.

${ }_{51}$ For Professor Oppenheim, only the conventions of war and not the laws and customs of war can be ignored in such a case, Ibid.

52 'Final plea for defendant Karl Brandt by Dr. Servatius', supra note 48, p. 127.

${ }^{53}$ According to this author, a member of the Nazi party from 1933 until 1936: 'Sovereign is he who decides on the exception', cf. Carl Schmitt, Political Theology, (1922, reissue Gallimard, Paris 1988), p. 15.

54 'Extracts from the closing brief against defendants Ruff, Romberg, and Weltz', Trials of War Criminals before the Nuernberg Military Tribunals Under Control Council Law $n^{\circ} 10$, vol. I: 'The Medical Case', Nuernberg, October 1946 - April 1949 (U.S. Government Printing Office, Washington, 1950), p. 113.

${ }^{55}$ Ibid.

${ }^{56}$ Ibid. A necessity of the state defined by Roberto Ago as 'The ... situation of extreme peril ... represents a grave danger to the existence of the State itself, its political or economic survival, the continued functioning of its essential services, the maintenance of internal peace, for the survival of a sector of its population, the preservation of the environment of its territory or part thereof, etc.', $c f$. Roberto Ago, 'The internationally wrongful act of the State, source of international responsibility, Addendum to the Eighth International Law Commission on State responsibility', U.N. Doc. A/CN.4/318/Add.5 à 7, in Yearbook of the International Law Commission, 1980-II(1), U.N. Doc. A/CN.4/SER.A/1980/Add.1 (Part 1), p. 14.

57 'Extracts from the closing brief against defendants Ruff, Romberg, and Weltz', supra note 54, p. 113. 
Final draft version (do not cite). Final version published in International Criminal Law

Review 17(6):1049-1069 05 Dec 2017

exceptions based on Kriegsraison ${ }^{58}$ does not therefore have to mean that the entire notion of military necessity also has to be dismissed out of hand.

By reaching the judgment that the experiments carried out by the Nazi doctors were, at the very least, contrary to the general principles of criminal law and Allied Control Council Law No. 10 but also more generally against international custom as set out by the Martens Clause $^{59}$, the court responded to the defense's use of the necessity argument to justify the experiments carried out. The judges emphasised that the reconciliation of military necessity with the requirements of humanity must be carried out within the framework of the laws and customs of war and that the result of this reconciliation cannot call into question '[the] laws of humanity and [the] requirements of the public conscience ${ }^{60}$. This means that a universally approved minimum level of humanity exists which no sovereignty has the right to override, between jus cogens and erga omnes norms.

\section{International Medical Ethics as a Source of Law}

Reaching a verdict about the doctors therefore required a level of basic humanity to be established within the bounds of the "moral, ethical and legal concepts' ${ }^{61}$ applicable to experiments on human beings. Set out over two pages of the verdict, ${ }^{62}$ the ten principles governing medical research on humans, the Nuremberg Code ${ }^{63}$ thus established a boundary between 'permissible medical experiments' ${ }^{64}$ and those which must be condemned at all times. The judges drew these principles from the debates between the respective parties involved in the trial about the practices generally accepted in experimental medicine throughout the world.

\footnotetext{
${ }^{58}$ The idea of Kriegsraison was also rejected by another chamber of this United States Military Tribunal in the Krupp case: 'It is an essence of war that one or the other side must lose and the experienced generals and statesmen knew this when they drafted the rules and customs of land warfare. In short, these rules and customs of warfare are designed specifically for all phases of war. They comprise the law for such emergency. To claim that they can be wantonly - and at the sole discretion of any one belligerent - disregarded when he considers his own situation to be critical, means nothing more or less than to abrogate the laws and customs of war entirely'; $c f$. US Military Tribunal at Nuremberg, US v. Alfried Krupp et al., 'Judgment', vol. IX: 'Krupp Case', (U.S. Government Printing Office, Washington, 1950) p. 1347. For a similar line of argument, also US. v. Wilhelm List, et al., 'Judgment', vol. XI: 'Hostage Case' (U.S. Government Printing Office, Washington, 1950), pp. 1252 et 1256; US v. Wilhelm von Leeb, et al., 'Judgment', vol. XI: 'The High Command Case' (U.S. Government Printing Office, Washington, 1950), p. 541.

${ }^{59}$ On the customary nature of the Martens Clause, the analysis developed by Antonio Cassese represents a useful source, 'The Martens Clause: Half a Loaf or Simply Pie in the Sky?', 11(1) European Journal of International Law (2000)187-216, and by Meron, supra note 31.

${ }^{60}$ Convention (II) with respect to the Laws and Customs of War on Land, The Hague, 29 July 1899, Preamble, al. 8 .

61 'Judgment', supra note 29, p. 181.

${ }^{6}$ Ibid., pp. 181-183.

${ }^{63}$ To understand the origins of the Code, insight is available in articles by Michael A. Grodin, 'Historical Origins of the Nuremberg Code', in George J. Annas, Michael A. Grodin (ed.), The Nazi Doctors and the Nuremberg Code. Human Rights in Human Experimentation (Oxford University Press, Oxford, 1992), pp. 121144; Harkness, supra note 17, pp. 1672-1675; Leonard A. Temme, 'Ethics in Human Experimentation: the Two Military Physicians Who Helped Develop the Nuremberg Code', 74(12) Aviation, Space, and Environmental Medicine (2003) 1297-1300; and the work by Horst H. Freyhofer, The Nuremberg Medical Trial: The Holocaust and the Origin of the Nuremberg Medical Code (Peter Lang Publishing, Berne, 2004).

64 'Judgment', supra note 29, p. 181.
} 
Both the defense and the prosecution appeared to agree that medical ethical norms could be used to interpret the legal framework applicable to this case. Thus, in view of the absence of a specific international rule targeting experimentation on humans, whether in time of war or of peace, the defense lawyers first of all reminded the tribunal of the necessary positivity of the rules applicable to the trial of their clients. ${ }^{65}$ Gebhardt's lawyer quite appositely insisted on the relationship between medical ethics and the law. He reminded the tribunal that any violation of medical ethics couldn't automatically be viewed as a crime; only the law can provide grounds for criminal charges. ${ }^{66} \mathrm{He}$ put it to the tribunal that, in contrast, the principles of medical ethics are important elements regarding interpretation of the law in this field. ${ }^{67} \mathrm{On}$ the opposite side - indeed from the very start of the trial - the prosecution stressed the Hippocratic Oath ${ }^{68}$ as the basis for research ethics regarding humans, accusing the Nazi doctors of having violated the Oath they had sworn to uphold, particularly with regard to the principle of doing no harm. ${ }^{69}$ The trial then saw the main arguments focus on the definition of the code of ethics applicable to the interpretation of 'elementary considerations of humanity'.

For Dr. Ivy, one of the American experts involved in the trial, the Hippocratic Oath was the 'golden rule', ${ }^{70}$ the law of reciprocity as applied to the field of medicine, ${ }^{71}$ namely a 'fundamental basic truth that is good for all time'. ${ }^{72}$ But he was not always entirely clear about the scope of the Oath. When cross examined by Dr. Tipp, one of the defense counsellors, on the subject of potentially fatal experiments carried out on prisoners who were condemned to death and who had volunteered for the experiments, ${ }^{73}$ he replied that the passage of the Oath forbidding the administration of a poison to a patient, even with their agreement, 'refers to the function of the physician as a therapist, not as experimentalist'. ${ }^{74}$ This would make the Oath a 'two-tier system' with certain passages not applying to medical science researchers. According to Michael Grodin, both Andrew Ivy and Leo Alexander, another American expert who shared the same point of view, 'confused therapeutic treatment of patients with nontherapeutic experimentation on prisoners and thus incorrectly cited Hippocrates as the source for the ethics of human experimentation'. ${ }^{75}$ This is supported by the fact that the Hippocratic Oath does not at any point mention the question of consent, which was very much a central one at Nuremberg. It does however set the requirement that treatment

\footnotetext{
${ }^{65}$ It is in this sense that Dr. Serviatus, Karl Brandt's lawyer, notably invokes the idea of natural law, asserting: 'One forgets that eternal law, the law of nature, is but a guiding principle for the state and the legislator and not a counter-code of law which the subject might use as a support against the state." ['Final plea for defendant Karl Brandt by Dr. Servatius', supra note 47, p. 126].

66 'Extract from the Final plea for defendant Gebhardt', Trials of War Criminals before the Nuernberg Military Tribunals Under Control Council Law n'10, vol. II: 'The Medical Case', p. 72.

${ }^{67}$ Ibid.

${ }^{68}$ A reference work providing an explanatory reading of the Hippocratic Oath is Steven H. Miles, The Hippocratic Oath and the Ethics of Medicine, Oxford University Press, 2004.

${ }^{69}$ Telford Taylor, 'Opening statement of the prosecution - December 9 ${ }^{\text {th }}$, 1946', supra note 22, p. 68.

${ }^{70}$ Transcripts, p. 9243. Cf. also Evelyne Schuster, 'Considérations', 160 Revue d'histoire de la Shoah (1997) 193-194.

${ }^{71}$ For an explanation and analysis of the concept of the 'golden rule', or law of reciprocity, see generally Olivier du Roy, La Règle d'or. Histoire d'une maxime morale universelle, 2 volumes (Éditions du Cerf, Paris, 2012); Jeffrey Wattles, The Golden Rule (Oxford University Press, Oxford, 1996).

${ }^{72}$ Transcripts, p. 9243. Cf. also Schuster, supra note 70, pp. 193-194.

${ }^{73}$ Experiments which Dr. Ivy seems to consider as complying with medical ethics. Cf. Transcripts, pp. 93159316.

73 'Extract from the Final plea for defendant Gebhardt', supra note 66, p. 72.

${ }^{74}$ Transcripts, pp. 9315-9316.

${ }^{75}$ Grodin, supra note 63, p. 124.
} 
Final draft version (do not cite). Final version published in International Criminal Law Review 17(6):1049-1069 05 Dec 2017

be beneficial to patients, which appears difficult to square with experiments which produce no direct therapeutic benefits - traditionally Phase I clinical trials ${ }^{76}$.

To back up his expertise, Andrew Ivy also called upon the research directives of the American Medical Association. ${ }^{77}$ Still it must be borne in mind that these directives were only published nineteen days before the start of the trial following a very short reflection period which began at the end of $1946 .{ }^{78}$ Dr. Sauter (the lawyer for Ruff and Romberg) also underlined this aspect when he stated that:

[A] German physician who in Germany performed experiments on Germans cannot be judged exclusively according to an American medical opinion, which moreover dates from the year 1945 and was coded in the years 1945 and 1946 for future use; it can also have no retroactive force. ${ }^{79}$

Thus, given that the Hippocratic Oath was seen to apply more to medical treatment than to medical research and, furthermore, that the existing ethical directives applied more to America than on an international basis, the defense accentuated a form of practical and genuinely international ethical code as the basis for the framework governing experiments on humans. Ruff's lawyer stressed that 'the human experiment is such a far-reaching and often such an indispensable matter that one might speak of an unwritten law, which generally and tacitly is accepted and acknowledged by the whole world' ${ }^{80} \mathrm{He}$ concluded that in the absence of a written law, doctors or researchers could only adopt what is expressed in international as opposed to solely American - medical literature as a conventional code of conduct. ${ }^{81} \mathrm{He}$ thereby asserted the existence of a form of international ethics as a source of interpretation of general law or even as a source of legal custom. A similar point of view can be found in Karl Brandt's defense. His lawyer used experiments generally carried out throughout the world, including in the United States, as a basis for his argument. Experiments for which the reports 'have so far been received without opposition by specialist circles, the authorities, and also the general public', ${ }^{82}$ led him to assert that it is possible to deduce what is allowable and fair. ${ }^{83}$ Via a deduction worthy of sociological positivism, ${ }^{84}$ the lawyer concluded that it was

\footnotetext{
76 'A Phase 1 study is defined as a non-therapeutic, exploratory trial in human subjects who may be healthy or have a specific disease. In contrast to later phase studies, subjects can usually expect no therapeutic benefit from a Phase 1 trial. The primary parameters tested in Phase 1 studies (...) are: Safety and tolerability, Pharmacokinetics, Pharmacodynamics', $c f$. Association of the British Pharmaceutical Industry, Guidelines for phase 1 clinical trials, 2012 edition, p. 8 [http://www.abpi.org.uk/our-work/library/guidelines/Documents/ guidelines_phase1_clinical_trials.pdf]

77 'Extract from the Testimony of Prosecution expert witness Dr. Andrew C. Ivy', Trials of War Criminals before the Nuernberg Military Tribunals Under Control Council Law $n^{\circ} 10$, Vol. II: 'The Medical Case', Nuernberg, U.S. Government Printing Office, 1952, pp. 82-86.

${ }^{78}$ Grodin, supra note 63, p. 134.

79 'Extract from the Testimony of Prosecution expert witness Dr. Andrew C. Ivy', supra note 77, p. 85 [emphasis added].

80 'Extract from the final plea for defendant Ruff', supra note 44, p. 991.

${ }^{81}$ Ibid.

82 'Extract from the closing brief for defendant Karl Brandt', supra note 42, p. 50.

${ }^{83}$ Dr. Serviatus bases this notably on the experiments carried out in American prisons; on this question $c f$. Harkness, supra note 17, pp. 1672-1675; Evelyne Shuster, 'Fifty Years Later: The Significance Of The Nuremberg Code', 13 The New England Journal of Medicine (1997), p. 1438.

${ }^{84}$ Cf. notably Stéphane Pinon, 'Le positivisme sociologique: l'itinéraire de Léon Duguit', 67 Revue interdisciplinaire d'études juridiques (2011) 69-93.
} 
Final draft version (do not cite). Final version published in International Criminal Law Review 17(6):1049-1069 05 Dec 2017

therefore possible to determine the legal rules applicable to the experiments. ${ }^{85} \mathrm{~A}$ similar argumentation was presented by Ruff's lawyer, for whom one of the central questions of this trial was the comparison of practices carried out by the accused with those which were internationally recognized and used by foreign researchers 'with the approval of all civilized humanity. ${ }^{86}$

\section{Consent to Human Experiments in a Coercive Context}

But during the exchanges, the only real comparison made between the various practices focused on the question of consent and elements regarding the scientific quality of the experiments only rarely came up, ${ }^{87}$ save to dismiss Nazi science a priori because it was inhumane.$^{88}$ It is interesting to note that, as late as the mid-1980s, the question of using data from high altitude or hypothermia experiments carried out in concentration camps was still being raised. In an article published in 1984, Kristine Moe noted that since 1945 at least fortyfive scientific articles had cited data from Nazi experiments. ${ }^{89}$ She underlined that '[d]espite the conventional wisdom, many of the scientists I spoke to regard the Nazi data as useful and necessary to their work'. In a 1945 report, initially classified as top-secret, Leo Alexander concluded that the experiments on hypothermia had been carried out under reliable conditions, ${ }^{90}$ judging that 'the final report by Holzlöhner, Rascher and Finke satisfies all the criteria of objective and accurate observation and interpretation. ${ }^{91}$ This question of the scientific reliability of Nazi medical experiments continues to divide authors, with categorical detractors ${ }^{92}$ and observers who take a more balanced view. ${ }^{93}$

In terms of consent, the defense lawyers sought to establish the crimes of Nazi researchers as the continuation of experiments carried out elsewhere in the world since the beginning of the $20^{\text {th }}$ century. They for instance recalled the experiments conducted in 1912 by Colonel Strong and Dr. Crowell on beriberi in Manila, Philippines, using prisoners condemned to death and presented as volunteers; those carried out on 'voluntary' prisoners in 1920 by Dr. Joseph Goldberger (Pellagra experiments) or since 1942 on malaria at Statesville Penitentiary, Illinois, under the direction of the University of Chicago; or the experiments on trench fever in 1917, using American soldiers, by a committee under the supervision of the Surgeon

\footnotetext{
${ }^{85}$ Extract from the closing brief for defendant Karl Brandt', supra note 42, p. 50: 'The experiments actually carried out are a mirror of the existing laws and one can by way of legal sociological investigation find the norms of law that have validity' [emphasis added].

86 'Extract from the closing brief for defendant Ruff', supra note 44, p. 93.

${ }^{87}$ Cf. notably the cross-examination by Dr. Ivy, Transcripts, pp. 9101-9132.

${ }^{88}$ Telford Taylor, 'Opening statement...', supra note 22.

${ }^{89}$ Kristine Moe, 'Should the Nazi Research Data Be Cited?', 14(6) The Hastings Center Report (1984), p. 5.

${ }^{90}$ Leo Alexander, Combined Intelligence Objectives Subcommittee, The Treatment of Shock from Prolonged Exposure to Cold, Especially in Water, Item No. 24 (Office of the Publication Board, Department of Commerce, Washington, DC, 1946).

${ }^{91}$ Ibid., p. 67

${ }^{92}$ Cf. notably Robert L. Berger, 'Nazi Science - The Dachau Hypothermia Experiments', 20 The New England Journal of Medicine (1990) 1435-1440; William E. Seidelman, 'Mengele Medicus: Medicine's Nazi Heritage', 2 The Milbank Quarterly (1988) 221-239.

${ }^{93}$ Cf. notably Arthur L. Caplan, 'How Did Medicine Go So Wrong?', in Arthur L. Caplan (ed.), When Medicine Went Mad. Bioethics and the Holocaust (Humana Press, New York, 1992), pp. 53-92; Robert N. Proctor, 'Nazi Science and Nazi Medical Ethics: Some Myths and Misconceptions', 43(3) Perspectives in Biology and Medicine (2000) 335-346.
} 
General of the U.S. Army and the American Red Cross. ${ }^{94}$ All of these situations took place under highly coercive conditions, whether the coercion was structural or hierarchical in nature. As emphasized by Gebhardt's lawyer, 'in nearly all countries experiments have been performed on human beings under conditions which entirely exclude volunteering in a legal sense. ${ }^{95}$ The voluntary nature of participation in the aforementioned experiments is highly questionable, and it could thus interrogate the affirmation, made by the accusation, of consent to take part in experiments as a universally recognized or accepted rule.

The lawyers for Karl Brandt, ${ }^{96}$ Siegfried Ruff ${ }^{97}$ and Karl Gebhardt ${ }^{98}$ also asserted that certain experiments could be carried out on prisoners without their consent, as a means of atoning for their crimes. The only criterion would therefore be that of proportionality between the risk to prisoners and the crimes they had committed. ${ }^{99}$ Dr. Serviatus cited the case of experiments on prisoners who had been sentenced to death, such as the ones in Manila on tetrachloroethane, ${ }^{100}$ or prisoners convicted under ordinary law, such as the experiments on malaria in three American penitentiaries. ${ }^{101} \mathrm{He}$ concluded that international medical doctrine allows in these cases for certain experiments to be carried out on prisoners even if criteria of consent or safety are not respected. On this point, the prosecution appeared to struggle to counter the defense's arguments, only attacking them concerning the legitimacy of the application of the death penalty to these categories of prisoners, and implicitly underlining the absence of a clear international policy in the field of clinical trials.

In view of this, the judges asserted in the first section of what is today known as the Nuremberg Code that:

\section{The voluntary consent of the human subject is absolutely essential.}

This means that the person involved should have legal capacity to give consent; should be so situated as to be able to exercise free power of choice, without the intervention of any element of force, fraud, deceit, duress, over-reaching, or other ulterior form of constraint or coercion; and should have sufficient knowledge and comprehension of the elements of the subject matter involved as to enable him to make an understanding and enlightened decision. This latter element requires that before the acceptance of an affirmative decision by the experimental subject there should be made known to him the nature, duration, and purpose of the experiment; the method and means by which it is to be conducted; all inconveniences and hazards reasonably to be expected; and the effects upon his health or person which may possibly come from his participation in the experiment.

\footnotetext{
${ }_{94}^{94}$ f. notably the cross-examination by Dr. Ivy, Transcripts, pp. 9141.

95 'Extract from the Final plea for defendant Gebhardt', supra note 66, p. 73 [emphasis added].

96 'Extract from the closing brief for defendant Karl Brandt', supra note 42, p. 950.

97 'Extracts from the Final Plea for Defendant Ruff', supra note 44, p. 992.

${ }^{98}$ Alfred Seidl (Dr. (Defense attorney)), Final Plea for the Defendant Dr. Karl Gebhardt, 9 June 1947, Trial Name: NMT 01. Medical Case - USA v. Karl Brandt and others, English Transcript: p. 10874 (15 July 1947), p. 51.

${ }^{98}$ Ibid., p. 986.

${ }^{99}$ Ibid., p. 986.

${ }^{100}$ G. R. Cameron, W. A. E. Karunaratne, 'Carbon tetrachloride cirrhosis in relation to liver regeneration', The Journal of Pathology and Bacteriology, vol. 42-1, 1936, pp. 1-21. Injection of tetrachloromethane was carried out prior to execution of the condemned prisoner and then, following execution, an autopsy was carried out to analyze the effects of the substance on the organism.

101 'Extract from the Closing Brief For Defendant Karl Brandt', supra note 42, p. 986. Cf. also Life, vol.18-23, 4 June 1945, pp. 43-46. The experiments were carried out on 800 prisoners spread among three correctional facilities in Atlanta, Illinois and New Jersey. This article begins with a symbolic phrase on the use of prisoners as guinea pigs: 'In three U.S. penitentiaries men who have been imprisoned as enemies of society are now helping science fight another enemy of society'.
} 
Final draft version (do not cite). Final version published in International Criminal Law

Review 17(6):1049-1069 05 Dec 2017

The duty and responsibility for ascertaining the quality of the consent rests upon each individual who initiates, directs or engages in the experiment. It is a personal duty and responsibility which may not be delegated to another with impunity ${ }^{102}$.

This extract from the verdict sets out a clear and precise basis for what would subsequently be called 'clear and informed consent' and it proved to be fundamental to future national and international standards in the biomedical field. The characteristics of such consent are that there should be no coercion of individuals, that the said individuals should be informed and that it should be ensured that they understand the information; in addition, repetition of this consent should be obtained by all researchers taking part in the clinical trials. However, despite its undoubted importance, this first principle, along with the ninth one concerning the right to withdraw consent at any stage, appears entirely disconnected from the contextual reality of experiments carried out during the period, in Germany or elsewhere. Whether they were carried out in prison, on socially disadvantaged and often illiterate sectors of the population, on medical students or on soldiers, these practices occur within contexts which are inherently coercive and under which it seems delusive to talk of free and informed consent.

The other eight principles, aimed at defining what constitutes moral science, as well as quality science, thus look like an attempt to apply a respectable veneer justifying the liberty taken with regard to reality. The question is still valid today in the context of Phase I (no direct therapeutic benefits) clinical trials, notably with regard to the accusation that the poorest sectors of the population are being exploited to the benefit of the rest of the population. In the United States, Carl Elliot has for example studied cities like Austin and Philadelphia, where 'the drug-testing economy has produced a community of semi-professional research subjects, who enrol in one study after another. Some of them do nothing else. For them, "guineapigging," as they call it, has become a job'. ${ }^{103}$ Without going into the details of the intense debate which has been raging since the start of the $21^{\text {st }}$ century about the ideas of exploitation and undue inducement in biomedical research, ${ }^{104}$ it is interesting to recall that Dr. Serviatus, Karl Brandt's lawyer, stated that in a naturally coercive context, validity of consent should be evaluated in terms of two criteria: knowledge of the risk involved and the advantages that the subjects think they will gain. ${ }^{105}$ According to the lawyer, subjects should be proportionally rewarded depending on the seriousness of the risks incurred. Thus a level of compensation which is too low in relation to the risks incurred would also denote an enforced experiment. ${ }^{106}$ To back this up, he pointed to the experiments on pellagra carried out in 1915 by Joseph

\footnotetext{
102 'Judgment', supra 29, pp. 181-182.

${ }^{103}$ Carl Elliot, 'Guinea-Pigging', The New Yorker, 7 January 2008, pp. 36-41 <http://nyr.kr/1L7qO7k>. This article became chapter 1 in: Carl Elliot, White Coat Black Hat. Adventures on the Dark Side of Medicine (Beacon Press, Boston, 2010). On the same subject, $c f$. Roberto Abadie, The Professional Guinea Pig: Big Pharma and the Risky World of Human Subjects (Duke University Press, Durham, 2010).

${ }^{104} \mathrm{Cf}$. among others Carl Elliott, Roberto Abadie, 'Exploiting a Research Underclass in Phase 1 Clinical Trials', 358 NEJM (2008) 2316-2317; Giuseppe Pasqualetti et al., 'Healthy volunteers and early phases of clinical experimentation', 66(7) European Journal of Clinical Pharmacology (2010), p. 650; Trisha B. Phillips, 'Exploitation in payments to research subjects', 25(4) Bioethics (2011) 209-219; Leanne Stunkel, Christine Grady, 'More than the money: a review of the literature examining healthy volunteer motivations', 32(3) Contemporary Clinical Trials (2011) 342-352; Jeremy Snyder, 'Exploitations and their complications: The necessity of identifying the multiple forms of exploitation in pharmaceutical trials', 26(5) Bioethics (2012) 251258.

105 Ibid.

106 'Extract from the Closing Brief For Defendant Karl Brandt', supra note 42, p. 985.
} 
Goldberger at Rankin State Prison, Mississippi (Pellagra experiments ${ }^{107}$ ), those on leprosy carried out on prisoners who had been condemned to death at Billibid Penitentiary, Manilla, Philippines, ${ }^{108}$ or the ones performed at San Quentin Penitentiary in San Quentin in 1946, ${ }^{109}$ and for which no compensation was given to prisoners. According to Dr. Serviatus, therefore, only 'if both basic conditions are fully met will it be possible for the prisoner to make a free decision'. 110

Although it would be counterproductive here to resort to reductio ad Hitlerum ${ }^{111}$ to discredit all arguments in favour of inducement to take part in clinical trials, this reference to the arguments raised in Nuremberg at least links the question of consent to the inherently coercive context of certain situations. As important and necessary as the Doctors' Trial was, the American judges were unfortunately unable to bring about a departure from the traditional archetype of the decontextualized legal relationship.

This aspect of the trial has, in large part, been overlooked since the Second World War. Due to their exceptionally inhumane nature, ${ }^{112}$ the facts of this trial have never really brought about any genuine reflection or consideration on the part of the medical profession or state institutions. And as Sophie Monnier emphasizes in her thesis, 'the all-encompassing importance of corporatism, ${ }^{113}$ which predominated after this war led to all focus being placed on quality of science alone rather than on the potential violence of the contexts in which this activity can occur.

\footnotetext{
${ }^{107}$ Joseph Goldberger, W. F. Tanner, 'A Study of the Treatment and Prevention of Pellagra. Experiments Showing the Value of Fresh Meat and of Milk, the Therapeutic Failure of Gelatin, and the Preventive Failure of Butter and of Cod-Liver Oil', 39(3) Public Health Reports (1924) 87-107; for a critical analysis of the use of prisoners in this experimentation, Cf. Jon M. Harkness, 'Prisoners and pellagra', 111(5) Public Health Report (1996) 463-467. And more generally concerning experiments on prisoners in the U.S., Cf. his thesis: Jon M. Harkness, Research Behind Bars: A History of Nontherapeutic Research on American Prisoners (University of Wisconsin, 1996).

${ }^{108}$ Paul F. Russell, 'Biological and Medical Research at the Bureau of Science, Manila', 10(2) The Quarterly Review of Biology (1935) 119-153.

109 'Extract from the Closing Brief For Defendant Karl Brandt', supra note 42, p. 985; for a presentation of the experiment by its authors C $f$. Lowell A. Rantz, Elizabeth Randall, Helen H. Rantz, 'Immunization of human beings with group A hemolytic streptococci', 6(4) The American Journal of Medicine (1949) 424-432. San Quentin Prison was, at the time, a center for human experiments under the direction of its head physician Dr. Leo L. Stanley. The latter had himself tested one technique for transplanting human testicles and another involving injection of a homogenate of rams' testicles into volunteer prisoners between 1919 and 1920, cf. Leo L. Stanley, 'Experiences in Testicle Transplantation', 18(7) California State Journal Of Medicine (1920) 251253. Dr. Stanley's research seems to be concomitant with that of the Franco-Russian surgeon Serge Voronoff, who carried out transplants of human testicles and especially monkey testicles in the 1920s $C f$. notably Serge Voronoff, Greffes Testiculaires (Librairie Octave Doin, Paris, 1923).

110 'Extract from the Closing Brief For Defendant Karl Brandt', supra note 42, p. 985.

${ }^{111}$ Leo Strauss, Natural Right and History (University of Chicago Press, Chicago, 1953), p. 42.

${ }^{112} C f$. notably Norman Howard-Jones, 'Human experimentation in historical and ethical perspectives', 16 Social science and medicine law (1982), p. 1443; Robert N. Proctor, 'Nazi Science and Nazi Medical Ethics: Some Myths and Misconceptions', 43(3) Perspectives in Biology and Medicine (2000) 335-346. According to this author, the myth of Nazi 'false science', as notably recorded by the prosecution, 'served to reassure the American public that abuses like those of the Nazi era could never occur in a liberal democracy. Nazi science was pseudo-science, science out-of-control; American science was genuine science, secure within democratic institutions, obedient to the rule of law. Post-war ethical codes of conduct could even be dismissed as unnecessary - after all, weren't they designed to prevent abuses that could only occur in a totalitarian society, see Ibid., p. 336.

${ }^{113}$ Sophie Monnier, Les Comités d'Ethique et le Droit. Eléments d'analyse sur le système normatif de la bioéthique (L'Harmattan, Paris, 2005) p. 79.
} 